\title{
STRATEGI KEPALA SEKOLAH DALAM MEWUJUDKAN LEMBAGA PENDIDIKAN YANG UNGGUL DI PENDIDIKAN ANAK USIA DINI AL-MUNAWAROH PAMEKASAN
}

\author{
Siti Norhayati dan Jamiludin Usman \\ Institut Agama Islam Negeri Madura, Jawa Timur, Indonesia \\ Email : sitinorhayati275@gmail.com dan jamiludin.usman@iainmadura.ac.id
}

\begin{abstract}
Abstrak
Pokok pembahasan dalam penelitian ini yaitu strategi kepala PAUD dalam mewujudkan PAUD unggul, modal sosial yang dimiliki sekolah, serta faktor penghambat kepala sekolah dalam mewujudkan PAUD unggul di PAUD AlMunawwarah Pamekasan. Penelitian ini menggunakan rancangan studi kasus dengan pendekatan kualitatif. Hasil dari penelitian menunjukkan bahwa strategi kepala sekolah dalam mewujudkan PAUD unggul yaitu seorang kepala sekolah harus memiliki visi misi yang jelas, serta seorang kepala sekolah bersikap ramah kepada para guru, wali murid, dan juga kepada siswa. Selain itu seorang kepala sekolah harus memberikan suatu pelayanan yang baik kepada para tamunya. Institusi harus memiliki modal sosial dengan menjalin suatu hubungan baik dengan masyarakat sekitar lembaga ataupun masyarakat luar dan bekerjasama dengan beberapa instansi, serta memberikan suatu pelayanan yang baik kepada para tamu. Faktor penghambatnya yaitu daripribadi kepala yang harus mengenal karakter semua guru dan juga harus mengimbangi wali murid dengan baik, dan wali murid tidak setuju dengan program sekolah.
\end{abstract}

\section{Kata Kunci : Strategi, Kepala PAUD, PAUD Unggul}

\begin{abstract}
The main discussion in this study is the strategy of the PAUD head in realizing superior PAUD, the social capital owned by the school, and the inhibiting factors for the principal in realizing superior PAUD in PAUD Al-Munawwarah Pamekasan. This research uses a case study design with a qualitative approach. The results of the study indicate that the principal's strategy in realizing superior PAUD is that a principal must have a clear vision and mission, and a principal is friendly to teachers, parents, and also to students. In addition, a school principal must provide a good service to his guests. Institutions must have social capital by establishing a good relationship with the community around the institution or the outside community and collaborating with several agencies, as well as providing a good service to guests. The inhibiting factor is from the personal head who must know the character of all teachers and must also balance the guardians of students well, and the guardians of students do not agree with the school program.
\end{abstract}

Keywords : Strategy, head of early childhood education, PAUD Excels 


\section{PENDAHULUAN}

Kepala Pendidikan Anak Usia Dini (PAUD) adalah seorang pemimpin yang menggerakkan pendidik, peserta didik, wali peserta didik dan stakeholders PAUD lainnya untuk melakukan berbagai aktivitas yang diinginkannya. Hal itu disebabkan bahwasanya hakikat dalam memimpin merupakan upaya mempengaruhi seseorang ataupun sekelompok orang pada suatu organisasi ataupun lembaga, termasuk lembaga PAUD. ${ }^{1}$ Mengenai sumber daya manusia yang ada di lembaga peran dan fungsi pendidikan merupakan faktor yang sangat penting. Pentingnya peran seorang pendidik disini dalam mencapai tujuan pendidikan ini perlu di pahami dengan baik termasuk dalam Pendidikan Anak Usia Dini.

Melalui pendidikan anak usia dini kita dapat membangun sumber daya manusia yang mampu bersaing dengan sumber daya manusia dari Negara lain. Seorang pendidik juga harus mampu memberikan suatu pelayanan yang terbaik bagi anak didiknya. Menjadi pendidikan anak usia dini tidaklah mudah, bahkan lebih sulit di antara jenjang pendidikan lainnya. Selain harus memiliki rasa sayang yang sangat besar kepada anak dan personalitas yang baik, menarik, dan energik, seorang guru juga harus menguasai ilmu pendidikan, psikologi perkembangan anak, konsep-konsep dasar bidang studi, dan ilmu pembelajaran anak. ${ }^{2}$

Dalam perkembangannya masyarakat telah menunjukkan kepedulian terhadap masalah pendidikan, pengasuhan, dan perlindungan anak usia dini sejak berusia 0 sampai dengan 6 tahun dengan berbagai layanan sesuai dengan kondisi dan kemampuan yang ada, baik dalam jalur pendidikan formal ataupun pendidikan nonformal. Penyelengaraan PAUD jalur pendidikan formal berbentuk Taman Kanak-Kanak (TK)/Raudatul Atfal (RA). Di dalam jalur pendidikan non formal berbentuk Taman Penitipan Anak (TPA), Kelompok Bermain (KB), Taman Pendidikan Quran (TPQ), Satuan Pendidikan Sejenis (SPS), dan lainnya. ${ }^{3}$

Sekolah unggulan adalah sekolah yang mampu membawa setiap siswa mencapai kemampuannya secara terukur dan mampu menunjukkan prestasinya. Sekolah unggulan dianggap sekolah bermutu, namun dalam penerapannya, banyak kalangan menganggap bahwa dalam kategori unggulan tersirat harapan apa yang akan diberikan kepada anak didik pada saat lulus. Harapan itu sangat penting dan sangat dibutuhkan oleh setiap orang tua siswa, pemerintah, masyarakat bahkan oleh anakdidik itu sendiri, yaitu sejauh mana out put dan outcome sekolah memiliki kemampuan intelektual, moral dan keterampilan yang dapat berguna bagi masyarakat, negara dan agama. ${ }^{4}$

Dalam mewujudkan lembaga yang memiliki kualitas bermutu, setiap lembaga tentu harus memiliki spirit, nilai-nilai, keyakinan-keyakinan, slogan-slogan atau moto dan upacara yang baik. Sekolah/lembaga harus mengembangkan spirit, nilai-nilai

\footnotetext{
${ }^{1}$ Novan Ardy Wiyani, Manajemen Paud Bermutu Konsep Dan Praktik MMT Di KB, TK/RA (Yogyakarta: Gava Media, 2015), 97.

2 Adim Dwi Putranti and Dedy Achmad Kurniady, "Kepuasan Kerja Guru Terhadap Organizational Citizenship Behaviour ( OCB ) Guru TK Se-Kabupaten Kudus," Jurnal Adminisistrasi Pendidikan XVII, no. 1 (2013): 2.

3 Arifah Imtihani, "Strategi PengelolaanRaudatul Atfal (RA) Menjadi Paud Unggulan," Al Athfal 1, no. 1 (2018): 108, https://www.ejournal.stainupwr.ac.id/index.php/Al_Athfal/article/view/51.

4 Syarifah Rahmah, "Mengenal Sekolah Unggulan," ITQAN : Jurnal Ilmu-Ilmu Kependidikan 7, no. 1 (2016): 14, http://ejurnal.iainlhokseumawe.ac.id/index.php/itqan/article/view/112.
} 
persaudaraan, kejujuran, kesederhanaan dan cara demokrasi yang baik. ${ }^{5}$ Sedangkan konteks dalam Indonesia, kualitas lembaga PAUD ditentukan oleh tiga faKtor utama setelah suatu sekolah/lembaga diakreditasi dengan nilai tertentu oleh (Badan Akreditasi Nasional Pendidikan Anak usia Dini dan Pendidikan Non Formal/BAN PAUD-PNF). Ketiga faktor tersebut meliputi input, prosedur, dan out come yang telah distandarisasi. Input mengacu pada modal yang dimiliki sekolah, seperti sumberdaya sekolah, fasilitas, dan karakteristik awal peristiwa, sedangkan prosedur mengacu pada proses-proses pendidikan yang digunakan untuk mencapai hasil-hasil yang distandarisasikan. ${ }^{6}$

Dalam hal ini di PAUD Al-Munawaroh Pamekasan termasuk salah satu sekolah favorit yang berada di JalanBrawijaya, No 1 Pamekasan. Lokasinya cukup strategis karena jauh dari keramaian sehingga dalam proses pembelajaran bisa berjalan dengan baik. Selain lokasinya yang strategis, disana juga mempunyai pendidik yang ketika dilihat dari kinerja dan kompetensi yang sangat bagus karena pendidik disana sangat pintar dalam memilih metode dan strategi yang akan digunakan dalam proses pembelajaran. Karena selain pendidik peserta didik disana juga memiliki tatakrama yang bagus.

PAUD Al-Munawwarah berdiri berasaskan islam sebagai pedoman utama, lembaga ini merupakan lembaga yang berkomitmen untuk mengembangkan pendidikan anak usia dini. Sekolah ini telah berdiri sekian lama yaitu pada tahun 1991 hingga saat ini denga nmenyandang predikat Akreditasi A. PAUD Al-Munawwarah tergolong cukup terkenal di daerah Pamekasan karena PAUD Al-Munawwarah dapat lebih unggul menyaingi beberapa PAUD pada umumnya.

PAUD Al-Munawwarah sering kali menghadirkan inovasi di setiap kegiatan dalam pembelajaran. Metode yang digunakan oleh guru-guru tergolong cukup baik sehingga PAUD Al-Munawwarah dapat melahirkan murid-murid yang berprestasi di setiap perlombaan seperti halnya pada saat lomba mewarnai dan lomba tahfidz. Dan lembaga PAUD Al-Munawwarah memiliki program unggulan yaitu sholat dhuha berjamaah dan berwudhu'. Dengan begitu, PAUD Al-Munawwarah dapat membuktikan bahwa sekolah ini bisa menjadi acuan dengan sistem yang telah dijalankan, ini membuktikan bahwa lembaga ini memiliki kredibilitas yang baik. ${ }^{7}$

Maka dari itu peneliti tertarik mengangkat judul strategi kepala PAUD dalam mewujudkan PAUD unggul (studi kasus PAUD Al- Munawarah Pamekasan) karena peneliti ingin mengetahui lebih mendalam mengenai model strategi pembelajaran apa yang digunakan/dipakai paud al-munawwarah dalam mewujudkan PAUD unggul, apa saja modal sosial yang dimiliki sekolahdalam mewujudkan paud unggul, serta apa saja faktor penghambat kepala sekolah dalam mewujudkan paud unggul di PAUD AlMunawwarah Pamekasan.

\section{METODE PENELITIAN}

Dalam penelitan yang berjudul Strategi Kepala PAUD Dalam Mewujudkan PAUD Unggul (Studi Kasus PAUD Al-Munawwarah Pamekasan) yang dilakukan oleh peneliti menggunakan rancangan penelitian studi kasus dengan pendekatan kualitatif

\footnotetext{
${ }^{5}$ Rahmah, 206.

${ }^{6}$ Raihani, Kepemimpinan Sekolah Transformatif (Yogyakarta: LKiS, 2010), 9-10.

${ }^{7}$ Wawancara dengan Ibu Yuliatul Hasanah pada hari Rabu, Tanggal 30 Oktober 2019, Jam 09:35Selesai
} 
dengan jenis studi kasus. Penelitian studi kasus dimaksudkan untuk mempelajari secara insentif tentang latar belakang masalah keadaan dan posisi suatu peristiwa yang sedang berlangsung saat ini, serta interaksi lingkungan unit sosial tertentu yang bersifat apa adanya. ${ }^{8}$

Lokasi penelitian ini adalah di PAUD Al-Munawwarah Pamekasan, dan instrumen penelitiannya adalah orang (human instrument) yaitu peneliti sendiri. ${ }^{9}$ Sumber data diri penelitian ini berupa data primer dan data sekunder. Teknik pengumpulan data dengan observasi nonpartisipan (non participan observation), hasil Wawancara mendalam (in-depth interview), dokumentasi, dan kepustakaan. Analisis data bersifat induktif, dan hasil penelitian lebih menekankan pada makna daripada generalisasi. ${ }^{10}$

Menurut Bogdan dan Biklen sebagaimana yang dikutip oleh Lexy J. Moleong bahwa analisi data kualitatif adalah upaya yang dilakukan dengan jalan bekerja dengan data, mengorganisasikan data, memilah-milahnya menjadi satuan yang dapat dikelola, mencari dan menemukan pola, menemukan apa yang penting dan apa yang dipelajari, dan memutuskan apa yang dapat diceritakan kepada orang lain. ${ }^{11}$ Adapun analisis data dalam penelitian kualitatif adalah reduksi data, display data, dan kesimpulan dan verifikasi data.

Untuk pengecekan keabsahan data, penelitian ini menggunakan perpanjangan keikutsertaan, ketekunan pengamatan, dan triangulasi. Dalam penelitian ini, triangulasi yang akan digunakan oleh peneliti ialah triangulasi sumber. Karena dari triangulasi tersebut sudah cukup untuk memberikan jawaban tentang keabsahan data yang diperoleh.

\section{HASIL DAN PEMBAHASAN}

\section{Strategi Kepala Sekolah Dalam Mewujudkan PAUD Unggul di PAUD Al- Munawwarah Pamekasan}

Strategi adalah upaya yang sistematis melalui pengintegrasian dari tujuan, sasaran, kebijakan, program, dan kegiatan untuk mencapai misi secara efektif dan efisien. ${ }^{12}$ Strategi juga merupakan suatu cara atau taktik yang digunakan untuk mencapai suatu tujuan tertentu yang sudah terencana dengan baik oleh setiap anggota organisasi yang ada. Dengan adanya strategi juga kita dapat lebih mudah untuk mencapai tujuan yang kita inginkan. ${ }^{13}$

\footnotetext{
${ }^{8}$ Imam Gunawan, Metode Penelitian Kualitatif Teori \& Praktek (Jakarta: PT. Bumi Aksara, 2014), 112.

${ }^{9}$ Sugiono, Metode Penelitian Dan Pengembangan (Bandung: Alfabeta, 2016), 15.

10 Sugiono, Metode Penelitian Pendidikan Pendekatan Kuantitatif, Kualitaitif, Dan R Dan D (Bandung: Alfabeta, 2016), 15.

11 Lexy J. Moleong, Metodologi Penelitian Kualitatif (Bandung: Remaja Rosdakarya, 2011), 248.

12 Husaini Usman and Nuryadin Eko Raharjo, "Strategi Kepemimpinan Pembelajaran Menyongsong Implementasi Kurikulum 2013," Jurnal Cakrawala Pendidikan 5, no. 1 (2013): 2, https://doi.org/10.21831/cp.v5i1.1253.

13 Mohammad Hidayatul Ahsan and Jamiludin Usman, "STRATEGI PERSUASIF DALAM PENGEMBANGAN HUBUNGAN SOSIAL RELIGIUS ANTARA SISWA DAN TENAGA KEPENDIDIKAN DI LINGKUNGAN MTSN 2 PAMEKASAN," Re-JIEM (Research Journal of Islamic Education Management) 2, no. 2 (2019): 254, https://doi.org/https://doi.org/10.19105/rejiem.v2i2.2869.
} 
Strategi yang digunakan kepala sekolah PAUD dalam mengimplementasikan PAUD unggulan terdiri dari dua bagian, pertama, pengembangan internal yang meliputi: (1) menumbuhkan profesionalisme SDM guna mencapai keunggulan atau prestasi, (2) mengembangkan kurikulum, (3) melakukan pembinaan diri melalui kegiatan magang dan studi banding ke sekolah-sekolah nasional plus dan internasional dalam menerapjkan inovasi pembelajaran, (4) membentuk Kelompok Kerja Pendidikan (KKP) yang bertugas merancang kurikulum, strategi pembelajaran, membuat media dan sharing keilmuan tentang PAUD.

Dampak dari penerapan strategi ini adalah tumbuhnya pembiasaan improvisasi para pendidik yang dilakukan secara terus-menerus, tercapai pembuatan kurikulum dan pelaksanaan pembelajaran BCCT, juga tercapainya berbagai prestasi tingkat local sampai nasional yang dicapai lembaga maupun para pendidiknya.

Kedua, pengembangan eksternal yang meliputi: (1) pembinaan permagangan dan training pada Pos PAUD, (2) dilaksanakan kegiatan ilmiah, seperti pelatihan manajemen PAUD, pembelajaran dan seminar tentang ke PAUDan, (3) membuka diri menjadi pusat magang da studi banding. Dampak dari pelaksanaan pengembangan eksternal ini telah menghantarkan PAUD menjadi pusat pengembangan keunggulan PAUD. ${ }^{14}$

Temuan dari penelitian terhadap strategi kepala sekolah dalam mewujudkan PAUD unggul di PAUD Al-Munawarah Pamekasan yaitu kepala sekolah memiliki visi misi yang jelas, memiliki sifat jujur dan keteladanan, dan juga seorang kepala sekolah harus bisa mengelola bagian kurikulum dengan baik. Selain itu juga, usaha yang dilakukan dalam mewujudkan paud unggul di PAUD AL-Munawwarah Pamekasan yaitu dari segi sarana dan teknik pembelajarannya harus mendukung, begitupun dari gurunya juga harus mendukung, sehingga akan menghasilkan anak yang sesuai dengan keinginan orang tua dan juga lembaga.

\section{Model strategi pembelajaran dalam mewujudkan PAUD unggul}

Model strategi pembelajaran yang digunakan PAUD Al-Munawwarah yaitu menggunakan kurikulum 13 dengan menggunakan model sentra, untuk pengenalannya yaitu dengan cara bermain, jadi belajar melalui bermain. Diantaranya macam-macam sentra yang digunakan yaitu: sentra alam, sentra persiapan, sentra seni, sentra peran, dan sentra balok. Macam-macam sentra tersebut adalah salah satu model sentra yang digunakan para guru pada saat proses belajar mengajar berlangsung.

Metode pembelajaran yang digunakan dalam paud holistik yaitu sentra atau moving play merupakan konsep berpindah dari sentra yang satu ke sentra yang lain. Ada beberapa metode yang bisa digunakan atau sesuai dengan program pembelajaran paud holistic diantaranya: metode bermain sambil belajar; metode yang berpusat pada anak; metode yang menjadikan lingkungan sekitar sebagai media pembelajaran; metode yang akan membuat anak merasa dihargai, nyaman, aman, dan bebas berkreasi; serta metode yang memfasilitasi kecerdasan holistik.

14 I. Arifin, "Strategi Kepala Sekolah Dalam Mengimplementasikan PAUD Unggulan Nasional," Jurnal Pendidikan Dan Pembelajaran Universitas Negeri Malang 18, no. 1 (2011): 29-35. 
Ada beberapa kelebihan menggunakan metode pembelajaran dengan model sentra pada anak usia dini, yaitu pertama, sentra merupakan sarana yang dapat memenuhi kebutuhan anak usia dini pada saat proses pembelajaran berlangsung. Kedua, dengan menggunakan sentra anak akan lebih mudah untuk bertanggung jawab terhadap pekerjaan mereka sendiri. Dan ketiga, membuat para guru mendapat banyak manfaat dari adanya metode sentra. ${ }^{15}$

PAUD Al-Munawwarah juga memiliki sarana dan prasarana yang bisa dikatakan baik. Karena apabila suatu proses belajar berlangsung tanpa diimbangi dengan sarana dan prasarana yang baik maka hasilnya kurang memuaskan. Dan juga PAUD Al-Munawwarah memiliki suatu program unggulan yang dilakukan atau dikerjaan setiap harinya yaitu, berwudhu' dan salat duha berjamaah.

Ciri khas paling penting dalam proses pembelajaran pada anak usia dini atau pada TK adalah pembelajaran melalui bermain. Sesuai dengan kodratnya bahwa setiap anak menyukai bermain. Anak usia dini sebagian besar akan menghabiskan waktunya untuk bermain, baik sendiri, dengan teman sebaya, maupun dengan orang yang lebih dewasa. Bentuk permainannya pun juga beragam. Berdasarkan fenomena tersebut, para ahli pendidian dan psikologi menentuan bahwa bermain merupakan faktor penting dalam kegiatan pembelajaran pada anak usia dini. Oleh karena itu, bermain menjadi esensi dan harus menjadi jiwa dari setiap kegiatan pembelajaran anak usia dini. ${ }^{16}$

Mengutip pernyataan Mayesty bagi setiap anak, bermain adalah kegiatan yang mereka lakukan sepanjang hari karena bagi mereka bermain adalah hidup dan hidup adalah permainan. Anak usia dini tidak membedakan antara bermain, belajar dan bekerja. Anak-anak umumnya sangat menikmati permainan dan akan terus melakukannya dimanapun mereka memiliki kesempatan.

Sedangkan menurut Piaget dalam Mayesty mengatakan bahwa bermain adalah suatu kegiatan yang dilakukan secara berulang-ulang/terus-menerusyang akan menimbulkan kesenangan/kepuasan bagi diri seseorang. Sedangkan parten memandang kegiatan bermain sebagai sarana sosialisasi, diharapkan melalui bermain dapat memberi kesepakatan anak bereksplorasi, menemukan, mengespresikan perasaan, berkreasi, dan belajar secara menyenangkan. Selain itu, kegiatan bermain dapat membantu anakmengenal tentang diri sendiri, dengan siapa anak hidup serta lingkungan tempat dimanaanak hidup.

Pembelajaran anak usia dini menganut pendekatan bermain sambil belajar atau belajar sambil bermain. Dunia anak-anak adalah dunia bermain. Dengan bermain, anak-anak menemukan dan mempelajari hal-hal atau keahlian baru dan belajar (learn) kapan harus menggunakan keahlian tersebut, serta memuaskan apa yang menjadi kebutuhannya (need). Lewat bermain, fisik anak akan terlatih, kemampuan kognitif dan kemampuan berinteraksi dengan orang lain akan berkembang. ${ }^{17}$

Hal yang terpenting dalam proses pembelajaran juga bisa terwujud dengan kondisi lingkungan yang mendukung. Lingkungan yang kondusif atau baik adalah lingkungan yang akan menghasilkan suatu kreativitas dari anak didik itu sendiri, dimana anak tersebut merasa aman dan bebas dalam mewujudkan kreasinya.

Arifin, 192.

16 Ahmad Susanto, Pendidikan Anak Usia Dini (Konsep Dan Teori) (Jakarta: Bumi Aksara, 2017), 131.

17 Yuliani Nuraini Sujiono, Konsep Dasar Pendidikan Anak Usia Dini (Jakarta: Indeks, 2009), 86-87. 
Pengaruh dari lingkungan kondusif ini, membuat anak didik bisa merasa senang dan tenang dalam melakukan bebagai aktivitasnya.

Ruangan dan halaman juga perlu diatur dengan benar untuk membangkitkan minat dan kreasi anak dengan cara meletakkan berbagai macam media pembelajaran secara menarik. Pengaturan ruangan dan halaman dapat disesuaikan dengan tema mingguan. Begitupun dengan metode pembelajaran yang dipilih hendaknya bisa merangsang bagi anak untuk bereksplorasi dan memanfaatkan benda-benda yang ada disekitarnya. ${ }^{18}$

Untuk mendukung proses pembelajaran berdasarkan kurikulum yang telah dicantumkan, Yayasan pendidikan paud harus memenuhi standar minimal sarana dan prasarana minimal yang telah ditentukan. Dalam pasal 45 ayat 1 UU No. 20 tahun 2003 dinyatakan bahwa "setiap satuan pendidikan formal ataupun nonformal harus menyediakan sarana prasarana yang memenuhi keperluan pendidikan sesuai dengan pertumbuhan perkembangan potensi fisik, kognitif, sosial, emosi, dan kejiwaan anak didik." 19

Sarana prasarana PAUD adalah pengelolaan secara efektif terhadap seluruh aset lembaga paud yang dimiliki. Beberapa bentuk aset sarana prasarana tersebut mencakup tanah dan bangunan paud, perangkat pembelajaran yang terdiri dari alatalat permainan edukatif, baik indoor maupun outdoor, dan lain sebagainya. ${ }^{20}$

Perangkat sarana dan prasarana di ruang tertutup adalah berisi berbagai fasilitas permainan indoor, seperti balok dengan berbagai ukuran, bola, benda menyerupai binatang, mobil-mobilan, dan lain sebagainya. Sarana prasarana ini akan merangsang kreativitas anak dengan memberdayakan sarana prasarana yang ada di ruangan tersebut. ${ }^{21}$

Sedangkan sarana prasarana di ruang terbuka (outdoor) atau lapangan. Isinya sama, yakni berbagai fasilitas pembelajaran atau permainan. Hanya saja, bentuk dan jenisnya lebih bervariasi sesuai dengan kondisi luar ruanganan yang ada ataupun lapangan. Maksud dari lapangan itu sendiri seperti sawah, kebun, tambak, dan peternakan. Semua kondisi tersebut dapat dimanfaatkan sebagai salah satu bentuk sistem layanan pembelajaran. $^{22}$

\section{Modal sosial yang dimiliki sekolah dalam mewujudkan PAUD unggul}

Modal sosial yang dimiliki sekolah/lembaga yaitu menjalin suatu hubungan baik/bekerjasama dengan masyarakat sekitar lembaga ataupun dengan masyarakat luar (wali murid) agar dapat menghasilkan anak yang sesuai dengan keinginan orang tua dan lembaga serta meningkatkan performa siswa dan memperkuat peran keluarga. Selain dengan masyarakat PAUD Al-Munawwarah juga bekerja sama dengan beberapa instansi yang ada kaitannya dengan pembentukan paud holistikintegratif. Paud holistik yaitu paud yang memiliki kerjasama dengan beberapa instansi terkait dengan program-program paud dan perkembangan jasmani dan rohani anak usia dini.

18 Susanto, Pendidikan Anak Usia Dini (Konsep Dan Teori), 127-28.

19 Suyadi, Manajemen PAUD TPA-KB-TK/RA (Yogyakarta: Pustaka Pelajar, 2011), 21.

20 Suyadi, 176.

21 Suyadi, 183.

22 Suyadi, 188-89. 
Pengembangan anak usia dini (PAUD) holistik-integratif merupakan suatu pengembangan bagi anak usia dini yang dilaksanakan berdasarkan pemahaman untuk memenuhi kebutuhan esensial anak yang saling berkaitan secara simultan dan sistematis, yang meliputi berbagai aspek pengembangan secara fisik ataupun non fisik, supaya anak tersebut dapat tumbuh kembang sebagai anak yang sehat, kuat, cerdas, ceria, dan berbudi luhur. Sedangkan pertumbuhan anak secara fisik, mental, emosional, dan sosial dapat dipengaruhi oleh pemeliharaan kesehatan, pemenuhan gizi, pendidikan, dan psikososial (Bappenas). ${ }^{23}$

Program pembelajaran di PAUD holistik-integratif dituntut agar dapat melaksanakan suatu program secara holistik. Holistik artinya utuh dan menyeluruh, maksudnya adalah penyelenggaraan suatu program pembelajaran di paud akan dilaksanakan dalam rangka memfasilitasi pertumbuhan dan perkembangan jasmani dan rohani anak usia dini secara utuh dan menyeluruh. Program pembelajaran di paud bukan hanya tentang pendidikan saja, melainkan juga tentang masalah kesehatan. Sedangkan intgratif/terpadu adalah penanganan pada anak usia dini secara terpadu di tingkat masyarakat dimulai dari pemerintah daerah hingga pemerintah pusat. Program pembelajaran di paud, dilaksanakan dalam rangka upaya membangun manusia utuh dan sehat serta dapat mempersiapkan diri (anak) kejenjang pendidikan lebih lanjut. $^{24}$

Pemerintah juga menekankan pembelajaran paud holistik-integratif dalam Peraturan Presiden Republik Indonesia Nomor 60 Tahun 2013 yang menjelaskan bahwasanya pengembangan anak usia dini holistik-integratif yaitu upaya pengembangan anak usia dini yang dilakukan untuk memenuhi kebutuhan esensial anak yang beragam dan saling terkait secara sistematis dan terintegras.

Program PAUD yang holistik merupakan program pendidikan prasekolah yang dilaksanakan secara terencana dalam upaya pengembangan aspek jasmani dan rohani anak, yang meliputi gizi, kesehatan, dan pendidikan. Menurut Irawati dalam buku Pendidikan Anak Usia Dini, beliau mengatakan bahwasanya program yang holistik merupakan program yang dilakukan secara terintegrasi dalam satu kesatuan secara utuh dan professional. ${ }^{25}$ Tujuan khusus dari program paud holistik-integratif berdasarkan Persatuan Presiden Nomor 60 Tahun 2013 Pasal 2 Ayat (2) diantaranya: 1) membentuk anak berkepribadian utuh sejak dini (kecil), 2) terpenuhinya gizi, kesehatan, dan pendidikan bagi anak usia dini secara terpadu dalam rangka pertumbuhannya, 3) terlindunginya anak dari segala bentuk kekerasan, penelantaran, dan perlakuan yang salah terhadap seorang anak dimanapun mereka berada, 4) terselenggaranya suatu pelayanan bagi anak usia dini secara terintegrasi dan selaras antar lembaga, 5) terwujudnya suatu komitmen antara beberapa unsure yang terkait diantaranya, orang tua, keluarga, masyarakat, dan pemerintah dalam pengembangan paud holistik-integratif. ${ }^{26}$

23 Arri Handayani et al., "PENINGKATAN KUALITAS POS PAUD MELALUI PENGEMBANGAN PROGRAM HOLISTIK INTEGRATIF (Penelitian Tindakan Pada Pos PAUD Se-Kalurahan Penggaron Kidul)," Paudia : Jurnal Penelitian Dalam Bidang Pendidikan Anak Usia Dini 1, no. 1 (2012): 79, https://doi.org/10.26877/paudia.v1i1.260.

24 Susanto, Pendidikan Anak Usia Dini (Konsep Dan Teori), 182.

25 Susanto, 182-83.

26 Susanto, 184. 
Temuan penelitian dari fokus kedua mengenai modal sosial yang dimiliki PAUD Al-Munawwarah yaitu PAUD Al-Munawwarah bekerjasama dengan masyarakat sekitar lembaga ataupun dengan masarakat luar. Akan tetapi bukan itu saja melainkan PAUD Al-Munawarah juga bekerja sama dengan beberapa instansi yang berkaitan dengan pembentukan PAUD holistik-integratif. PAUD holistik yaitu paud yang memiliki kerjasama dengan beberapa instansi terkait dengan programprogram paud dan perkembangan jasmani dan rohani anak usia dini. Sedangkan usaha para guru dalam meningkatkan kepercayaan masyarakat sekitar lembaga ataupun masyarakat luar yaitu para guru tetap menjaga cara mengajar mereka kepada murid dengan baik dan juga para guru harus memberikan suatu pelayanan yang baik kepada para tamunya.

\section{Faktor penghambat kepala sekolah dalam mewujudkan PAUD unggul di PAUD Al-Munawwarah Pamekasan}

Berdasarkan hasil wawancara dan pengamatan, didapatkan temuan bahwa faktor penghambatnya yaitu, kurangnya dukungan dari orang tua siswa (murid), contoh halnya tidak setuju dengan adanya suatu program yang kami buat. Jadi dalam pelaksanaan suatu program harus adanya kerjasama antar sekolah dengan pihak wali murid.

Keterlibatan wali murid merupakan sebuah proses yang akan membantu orang tua dengan menggunakan kemampuan mereka untuk kepentingan bersama, baik itu untuk murid, wali murid dan untuk program anak usia dini. Murid, wali murid, dan program merupakan semua bagian dari proses, oleh sebab itu semua pihak akan diuntungkan dengan adanya keterlibatan yang terencana dengan baik. Dengan demikian, agar suatu kegiatan terencana dengan baik, maka kita harus bekerjasama dengan wali murid jika suatu kegiatan ingin berhasil.

Ada beberapa tipe keterlibatan orang tua, yang disajikan dalam fitur pelengkap Penerapan Program. Keterlibatan tersebut merupakan pendekatan komprehensif untuk bekerjasama dengan orang tua. Diantaranya tipe keterlibatan orang tua yaitu: ${ }^{27}$ (a) jalinlah kemitraan/kerjasama dengan orang tua siswa. Setiap anak itu unik, mereka memiliki kekuatan dan kelemahan yang berbeda, ataupun kesukaan dan ketidaksukaan yang berbeda pula. Untuk mencapai sasaran tersebut, kita harus menjalinkan kerjasama dengan keluarga anak di rumah. Dengan bekerjasama, kita dapat membangun sebuah keinginan yang sama yaitu keberhasilan pendidikan. (b) berkomunikasi dengan orang tua. Hubungan yang kuat antara wali murid dengan lembaga yaitu menjalin komunikasi yang baik. Komunikasi yang baik merupakan alat yang dapat memberikan motivasi kepada wali murid untuk meluangkan waktunya dan mendukung kegiatan pendidikan anak-anak mereka. (c) mendorong umpan balik. Untuk mendorong komunikasi antara wali murid dengan lembaga, kami memberikan ruang untuk menulis komentar/catatan wali murid di buletin. Penggunaan berbagai bentuk komunikasi akan membuat orang tua secara cepat memperoleh informasi mengenai kemajuan anaknya, sasaran kurikulum dan ide-ide mengenai cara yang terbaik untuk mencapai keberhasilan anak di sekolah. (d) berikan kantong PR. Kantong PR ini adalah mendorong hubungan baik antara orang

27 George S. Morrison, Dasar-Dasar Pendidikan Anak Usia Dini (PAUD) (Jakarta: Indeks, 2008), 375. 
tua dengan anaknya, karena mereka akan bekerjasama dalam mengerjakan keterampilan yang sama dengan yang diajarkan di sekolah. Orang tua akan memantau secara langsung perkembangan akademik anak sekaligus akan mengetahui kelemahan dan kelebihan anaknya. ${ }^{28}$

Temuan penelitian dari fokus ketiga mengenai faktor penghambat kepala sekolah dalam mewujudkan PAUD unggul dalam hal ini, faktor penghambatnya yaitu kurangnya partisipasi dari orang tua kepada lembaga terhadap program yang sudah dilaksanakan, dengan begitu seharusnya pihak lembaga dan orang tua harus mempunyai hubungan kerjasama yang baik, agar semua kegiatan di lembaga bisa terlaksana dengan lancar dan sesuai dengan tujuan.

\section{KESIMPULAN}

Berdasarkan uraian di atas dapat ditarik beberapa kesimpulan dan juga akan diberikan saran-saran mengenai strategi kepala PAUD dalam mewujudkan PAUD unggul di PAUD Al-Munawwarah Pamekasan. Kesimpulan pertama, Strategi kepala sekolah dalam mewujudkan PAUD unggul disini, seorang kepala sekolah harus memiliki visi misi yang harus jelas, seorang kepala sekolah harus ramah kepada para guru, wali murid, dan juga kepada siswa. Selain itu seorang kepala sekolah harus memberikan suatu pelayanan yang baik kepada para tamunya.

Kesimpulan yang kedua, mengenai modal sosial yang dimiliki lembaga PAUD Al-Munawwarah pamekasan adalah bekerjasama dengan beberapa instansi yang berkaitan dengan program-program PAUD dan juga bekerjasama dengan salah satu wali murid yang mempunyai sawah/kebun. Agar anak-anak bisa mengetahui beberapa manfaat dari tumbuh-tumbuhan yang mereka tanami.

Faktor penghambat kepala sekolah dalam mewujudkan PAUD unggul yaitu, dari diri kita sendiri maksudnya yaitu kita harus menomorduakan kepentingan pribadi, dan juga kita harus mengenal semua karakter dari para guru dan harus bisa mengimbangi wali murid dengan baik.

\section{DAFTAR PUSTAKA}

Ahsan, Mohammad Hidayatul, and Jamiludin Usman. "STRATEGI PERSUASIF DALAM PENGEMBANGAN HUBUNGAN SOSIAL RELIGIUS ANTARA SISWA DAN TENAGA KEPENDIDIKAN DI LINGKUNGAN MTSN 2 PAMEKASAN." Re-JIEM (Research Journal of Islamic Education Management) 2 , no. 2 (2019): 252-65. https://doi.org/https://doi.org/10.19105/rejiem.v2i2.2869.

Arifin, I. "Strategi Kepala Sekolah Dalam Mengimplementasikan PAUD Unggulan Nasional.” Jurnal Pendidikan Dan Pembelajaran Universitas Negeri Malang 18, no. 1 (2011): 29-35.

Gunawan, Imam. Metode Penelitian Kualitatif Teori \& Praktek. Jakarta: PT. Bumi Aksara, 2014.

Handayani, Arri, Muniroh Munawar, Anita Chandra D.S., and Dwi Prasetiyawati D.H. "PENINGKATAN KUALITAS POS PAUD MELALUI PENGEMBANGAN PROGRAM HOLISTIK INTEGRATIF (Penelitian Tindakan Pada Pos PAUD Se-

28 Morrison, 376-77. 
Kalurahan Penggaron Kidul)." Paudia: Jurnal Penelitian Dalam Bidang Pendidikan Anak Usia Dini 1, no. 1 (2012): 75-92. https://doi.org/10.26877/paudia.v1i1.260.

Imtihani, Arifah. "Strategi PengelolaanRaudatul Atfal (RA) Menjadi Paud Unggulan." Al Athfal 1, no. https://www.ejournal.stainupwr.ac.id/index.php/Al_Athfal/article/view/51.

Moleong, Lexy J. Metodologi Penelitian Kualitatif. Bandung: Remaja Rosdakarya, 2011.

Morrison, George S. Dasar-Dasar Pendidikan Anak Usia Dini (PAUD). Jakarta: Indeks, 2008.

Putranti, Adim Dwi, and Dedy Achmad Kurniady. "Kepuasan Kerja Guru Terhadap Organizational Citizenship Behaviour ( OCB ) Guru TK Se-Kabupaten Kudus.” Jurnal Adminisistrasi Pendidikan XVII, no. 1 (2013): 1-11.

Rahmah, Syarifah. "Mengenal Sekolah Unggulan." ITQAN: Jurnal Ilmu-Ilmu $\begin{array}{lllll}\text { Kependidikan } & 7, & \text { no. } & 1 & \text { (2016): }\end{array}$ http://ejurnal.iainlhokseumawe.ac.id/index.php/itqan/article/view/112.

Raihani. Kepemimpinan Sekolah Transformatif. Yogyakarta: LKiS, 2010.

Sugiono. Metode Penelitian Dan Pengembangan. Bandung: Alfabeta, 2016.

- Metode Penelitian Pendidikan Pendekatan Kuantitatif, Kualitaitif, Dan R Dan D. Bandung: Alfabeta, 2016.

Sujiono, Yuliani Nuraini. Konsep Dasar Pendidikan Anak Usia Dini. Jakarta: Indeks, 2009.

Susanto, Ahmad. Pendidikan Anak Usia Dini (Konsep Dan Teori). Jakarta: Bumi Aksara, 2017.

Suyadi. Manajemen PAUD TPA-KB-TK/RA. Yogyakarta: Pustaka Pelajar, 2011.

Usman, Husaini, and Nuryadin Eko Raharjo. "Strategi Kepemimpinan Pembelajaran Menyongsong Implementasi Kurikulum 2013." Jurnal Cakrawala Pendidikan 5, no. 1 (2013): 1-13. https://doi.org/10.21831/cp.v5i1.1253.

Wiyani, Novan Ardy. Manajemen Paud Bermutu Konsep Dan Praktik MMT Di KB, TK/RA. Yogyakarta: Gava Media, 2015. 